EDITORIAL

http://dx.doi.org/10.4314/mcd.v10i3s.1

\section{Madagascar's open landscapes under the spotlight}

Madagascar is known for its rich forests and endemic species, but also, unfortunately, for its ecosystem crises. Forests in Madagascar are diverse, ranging from tropical humid rain forests on the east to dry and spiny forests and thickets in the south and west. Forest biodiversity is high, with over $90 \%$ of mammalian species and more than $80 \%$ of the bird and amphibian species found in Madagascar existing only in forest habitats (Goodman and Benstead 2005). Thus, it is not surprising that forest ecosystems have attracted most attention in terms of biodiversity research and conservation. Protected areas such as National Parks or nature reserves are one of the most frequently used conservation strategies. Open landscapes and non-protected areas have received less attention although their relevance for Madagascar's biodiversity is indisputable. Madagascar is one of the poorest countries in the world, with more than $80 \%$ of the population living below the poverty line of \$US 1.25 per day (UNDP 2013). Pressure on the natural ecosystems is high, and unsustainable land use has already resulted in the loss of a significant part of the natural vegetation of the island. Forest ecosystem conversion or disturbance due to deforestation, mining, wood exploitation and invasive species is now a rapid and alarming phenomenon. The high level of habitat destruction in Madagascar has already caused the loss of several species (Harper et al. 2011) and has brought other species to the edge of extinction, for example, the lemurs is now considered as one of the most endangered group of mammals worldwide. There is thus an urgent need for sustainable land management and ecosystem restoration.

Both natural and anthropogenic open landscapes characterize most of the territory of Madagascar, including coastal ecosystems, fresh-water wetlands, grasslands and shrub dominated grasslands in the south. Open landscapes also provide several important ecosystem services that contribute to human wellbeing. For example, wetlands are one of the most undervalued ecosystems but offer several crucial provisional services (Van der Valk 2012), such as fishing, rice farming and raw materials such as reed or cyperus. Furthermore, they filter water and offer a unique habitat for several endemic species. Even several of the grasslands in Madagascar have developed after forest clearing; herbaceous vegetation is crucial for many purposes such as pasture for livestock, land cultivation, pine and eucalyptus plantations, providing useful plants for pharmaceuticals, and emblematic landscapes for tourism.

This special issue consists of six contributions and was initiated at the Open Landscapes conference - Ecology, Management and Nature Conservation, held in Hildesheim, Germany (29 September-3 October 2013). This special issue presents results covering a broad and representative sample of open landscape contexts in Madagascar. The term 'open landscape' used in this special issue is not as narrow in meaning as the academic sense. Rather, it refers to natural grasslands, lakes, wetlands, coastal ecosystems and open habitats that follow forest conversion.

Wetlands are diverse habitats and include both fresh-water and marine ecosystems (Van der Valk 2012). Madagascar is rich in fresh-water wetlands that are, along with the forests, areas with spectacular wildlife. One good example is the Mahavavy-Kinkony wetlands in western Madagascar. These wetlands hold all the wetland bird species of Western Madagascar, many of which are locally endemic. Another example of a wetland with a large number of locally endemic species is the Alaotra wetlands, which consist of Lake Alaotra and approximately 23,000 ha of freshwater marshes. Almost 50 bird species have been reported for the wetlands and open grasslands of the region (Pidgeon 1996), eight of them endemic to Madagascar and two of them endemic to Lake Alaotra, although they have been recently extirpated from the region (Hawkins et al. 2000). The Alaotra wetlands are also home to the critically endangered and locally endemic Alaotra Gentle Lemur (Hapalemur alaotrensis), the world's only primate species to live exclusively in wetlands. Alaotra is the biggest wetland complex in Madagascar, and many of the local communities depend on its ecosystems for their livelihoods. The lake constitutes the biggest rice and freshwater fish supply for Madagascar (Ferry et al. 2009). Due to increasing population growth and unsustainable land management, the Alaotra wetlands are continuously threatened by the conversion of marshland into rice fields, over-fishing and lake siltation (sediment pollution), caused by the erosion of deforested hills. An ecological investigation of the lake has shown that the lake and its freshwater marshes are highly degraded, as water levels and oxygen levels are very low (Lammers et al. 2015). The authors state that with an increasing human population, resulting in increased demand for fish and agricultural production, the Alaotra wetlands will undergo further pressures and it is unclear how much more the lake is likely to suffer in terms of alterations in water quality and vegetation in the future. Another problem that has worsened the situation is the invasion of the non-native water hyacinth (Eichhornia crassipes, Pontederiaceae), which is the source of various ecological and economic threats, as in many other regions of the world. The encroachment of this plant has been found to be closely correlated with human population density (Rakotoarisoa et al. 2015). Nevertheless, the plant, as well as other introduced species, might also constitute an opportunity as an alternative resource use option. According to these authors, the plant has the potential to improve local livelihoods and alleviate the pressure on the wetland complex by encouraging the use of simple and locally available tools. Given the limited access to credit and technology in the Alaotra region, the most likely use of the water hyacinth is for green manure, fodder, handicrafts, compost and ash as mineral fertilizer.

Grasslands constitute a major part of the open landscapes in Madagascar, especially in the southwest sub-arid ecosystems. As a consequence, the scarcity of resources such as water, arable land, exploited plants and animals may induce complex and unique traditional institutions that contribute to the management of resources and to dealing with conflicts regarding access. In these regions of scarcity, restrictions of access and resource exploitation linked to the establishment of a protected area may lead to severe consequences for the local inhabitants. Therefore, the quality of interactions between protected area managers or 


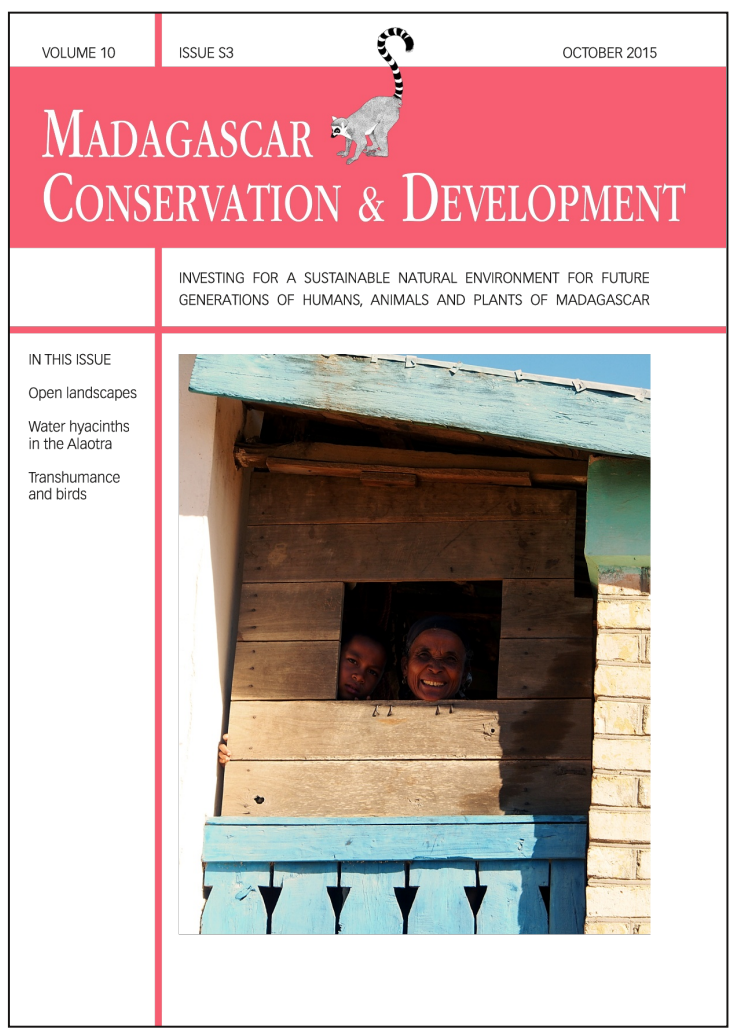

Madagascar Conservation \& Development is the journal of Indian Ocean e-Ink. It is produced under the responsibility of this institution. The views expressed in contributions to MCD are solely those of the authors and not those of the journal editors or the publisher.

All the Issues and articles are freely available at http://www.journalmcd.com

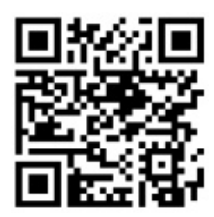

Contact Journal MCD

info@journalmcd.net for general inquiries regarding MCD funding@journalmcd.net to support the journal

Madagascar Conservation \& Development Institute and Museum of Anthropology

University of Zurich

Winterthurerstrasse 190

$\mathrm{CH}-8057$ Zurich

Switzerland

Indian Ocean e-Ink

Promoting African Publishing and Education

www.ioeink.com

Missouri Botanical Garden (MBG)

Madagascar Research and Conservation Program

BP 3391

Antananarivo, 101, Madagascar 
NGOs and local communities is crucial for the success of a project.

In these regions, the climate is particularly harsh and the local populations have developed subsistence strategies and practices (such as transhumance) to cope with these uncertain conditions. As observed in other parts of Madagascar, livestock is also one of the most important elements in the subsistence system, playing a socioeconomic and cultural role. As well as agricultural activities, livestock and pastoralism can have an impact on open landscape ecology and species diversity (although the latter remains unknown). Randriamiharisoa et al. (2015) show that the abundance of birds in the forests of Tsimanampesotse National Park has suffered from the transhumance, while species richness was not affected. Hunting pressure seems to be the main factor affecting the bird communities.

Cattle raids are found to be the main reason for the new transhumance movement, on the one hand, but are also the trigger for emerging socio-institutional constraints on transhumance (Goetter 2015). In her study, the emergence of the new pastoral movement is enhanced by pro-social norms of unconditional hospitality, shared property rights to fodder resources, mental models of kinship and formal indigenous institutions for trust creation. For socio-cultural environments principally ruled by informal indigenous institutions, the study stresses the importance of supportive social norms and fitting shared mental models for determining individual adaptation options.

In Madagascar, in many cases open landscapes are the consequence of forest conversion. Often neglected with regard to conservation policies as they are not considered wild enough, and because they are the direct consequence of deforestation, they nevertheless represent the major landscapes that surround forest protected areas where people have to survive (Carrière and Bidaud 2012). It is now recognised that the conservation effectiveness in the forests strongly relies on the ecological quality of the surrounding anthropogenic open landscapes (Perfecto and vandermeer 2010). Those landscapes may constitute one of the most suitable places to combine and reconcile human needs, livelihood security and sustainable use of forest species (Carrière and Bidaud 2012). A protected area induces substantial limitations of forest species and reduces access to agricultural lands. Open landscapes around forests play a major role as they are the direct buffer zones. Rural populations may shift from one native and endemic resource use to newcomer species available in their environment, but most of the time they prefer to choose a suitable mix of native and/or endemic species with new introduced ones. They see these species as highly complementary. As the local populations have demonstrated detailed knowledge of the silvicultural traits of a large number of tree species (Lavialle et al. 2015), they are able to manage native and introduced woody species. Alternatives to logging within the protected areas may offer a wider choice of tree species, including native ones. The cultivation of this diverse mix would allow people to take a more active part in the conservation and restoration of the natural capital at landscape scale (Lavialle et al. 2015). The use of non-native plant species is often viewed very critically. Nevertheless, as environmental (and especially soil) degradation is very severe throughout the country, the use of exotic plant species is often the only way to achieve a restoration goal. In addition, fast growing non-native species can lead to rapid habitat improvement.

There is a wide range of exotic species in Madagascar, resulting in the use of exotic and sometimes invasive species by native fauna and especially vertebrates (Kull et al. 2014). They provide food mainly for primates, flying foxes and birds, as well as habitat in open landscapes for all terrestrial vertebrate groups. Although these introduced plants should be viewed with caution due to their potentially invasive behaviour, many can provide services for the native fauna and humans (Kull et al. 2014). These plants could bridge the time lag until native forest regeneration or restoration with native trees has become effective (Gérard et al. 2015).

The situation at Lake Alaotra (as in other wetlands in Madagascar) gives some idea of how to use an open habitat for forest restoration. As soil degradation in the area is relatively high, the surrounding hills that were formerly covered with rainforest are now only covered with grasslands and no reforestation attempts have been initiated. Here, the invasive water hyacinth that covers much of the lake could play an important role as it is possible to make compost out of the plant which in turn could be used to enhance the soil quality and help to initiate reforestation perhaps starting with non-native plants - or to initiate agroforestry which in turn would have an economic benefit for the local communities.

Sadly, most natural and valuable open habitats are suffering in the same manner as Madagascar's forests from over-use and habitat destruction. This is alarming as a large part of the population's livelihoods depend directly on these ecosystems, and open landscapes play an important role for forest conservation. Focusing conservation, development and research efforts on open habitats is a necessity, given that actual drivers of land use, economic centers, and political decisions are currently at a crossroads; with the possibility of facilitating land use coordination, which might indirectly alleviate deforestation. Understanding the use of open landscapes by the majority of the rural population can help to provide best practices that preserve the adjacent forests, their biodiversity, ecosystem functions and services. Moreover, considering the current state of open habitats in Madagascar, they might well take a more prominent role in the island conservation narrative.

Jasmin Mantilla-Contreras

Institute of Biology and Chemistry

RG Ecology \& Environmental Education

University of Hildesheim

Universitätsstr. 1

31141 Hildesheim

Germany

mantilla@uni-hildesheim.de

Stéphanie M. Carrière

UMR GRED (Gouvernance, Risques, Environnement, Développement)

IRD-Montpellier (Institut de recherche pour le développement)

911 avenue Agropolis

34394 Montpellier Cedex 5

France

stephanie.carriere@ird.fr 


\section{REFERENCES}

Andriamandimbiarisoa, L., Blanthorn, T. S., Ernest, R., Ramanamanjato, J.-B., Randriatafika, F., Ganzhorn, J. U. and Donati, G. 2015. Habitat corridor utilisation by the gray mouse lemur, Microcebus murinus, in the littoral forest fragments of south eastern Madagascar. Madagascar Conservation \& Development 10, S3: 144-150. (doi:10.4314/mcd.v10i3s.7)

BirdLife International. 2014. Important Bird Areas factsheet: Mahavavy Kinkony Wetland. Website: $<$ http://www.birdlife.org/datazone/sitefactsheet.php?id=6546>.

Carrière, S.M. and Bidaud, C. 2012. En quête de naturalité: Représentations scientifiques de la nature et conservation de la biodiversité. Géopolitique et Environnement : les Leçons de l'Expérience Malgache. H. Rakoto Ramiarantsoa, C. Blanc-Pamard \& F. Pinton F. (eds.), pp 43-71. Objectifs Suds, IRD Marseille.

Ferry, L., Mietton, M., Robison, L. and Erismann, L. 2009. Le lac Alaotra a Madagascar - Passe, Present et Futur. Zeitschrift für Geomorphologie 53, 3 : 299-318.

Gérard, A., Ganzhorn, J. U., Kull, C. A. and Carrière, S. M. 2015. Possible roles of introduced plants for native vertebrate conservation: the case of Madagascar. Restoration Ecology. (doi:10.1111/rec.12246)

Goetter, J. F. 2015 (In press). The cattle raiders leave us no choice: New transhumance in the Mahafaly Plateau region in Madagascar. Madagascar Conservation \& Development 10, 4

Goodman, S. M. and Benstead, J. P. 2005. Updated estimates of biotic diversity and endemism on Madagascar. Oryx 39, 1: 73-77. (doi:10.1017/S0030605305000128)

Harper, G. J., Steininger, M. K., Tucker, C. J., Juhn, D. and Hawkins, F. 2007. Fifty years of deforestation and forest fragmentation in Madagascar. Environmental Conservation 34, 4: 325-333. (doi:10.1017/S0376892907004262)

Kull, C. A., Tassin, J. and Carrière, S. M. 2014. Approaching invasive species in Madagascar. Madagascar Conservation \& Development 9, 2: 60-70. (doi:10.4314/mcd.v9i2.2)

Lammers, P. L., Richter, T., Waeber, P. O. and Mantilla-Contreras, J. 2015. Lake Alaotra wetlands: how long can Madagascar's most important rice and fish production region withstand the anthropogenic pressure? Madagascar Conservation \& Development 10, S3: 116-127. (doi:10.4314/mcd.v10i3s.4)

Lavialle, J., Carrière, S. M., Miandrimanana, C., Tilahimena, A., Birkinshaw, C. R. and Aronson, J. 2015. Complementarity of native and introduced tree species: exploring timber supply on the east coast of Madagascar. Madagascar Conservation \& Development 10, S3: 137-143. (doi:10.4314/mcd.v10i3s.6)

Perfecto, I. and Vandermeer, J. 2010. The agroecological matrix as alternative to the land-sparing/agriculture intensification model. Proceedings of the National Academy of Science of the United States of America 107, 13 : 5786-5791. (doi:10.1073/pnas.0905455107)

Rakotoarisoa, T. F., Waeber, P. O., Richter, T. and Mantilla-Contreras, J. 2015. Water hyacinth (Eichhornia crassipes), any opportunities for the Alaotra wetlands and livelihoods? Madagascar Conservation \& Development 10, S3: 128-136. (doi:10.4314/mcd.v10i3s.5)

Randriamiharisoa, L. O., Rakotondravony, D., Raherilalao, M. J., Ranirison, A., Wilmé, L. and Ganzhorn, J. U. 2015. Effects of transhumance route on the richness and composition of bird communities in Tsimanampesotse National Park. Madagascar Conservation \& Development 10, S3: 110-115. (doi:10.4314/mcd.v10i3s.2)

UNDP 2013. Human Development Report 2013. The Rise of the South: Human Progress in a Diverse World. Available at $<$ http://hdr.undp.org/sites/default/files/reports/14/hdr2013 en_complete.pdf>

Van der Valk, A. G. 2012. The Biology of Freshwater Wetlands. Oxford University Press, New York 